\title{
Roles and Therapeutic Implications of Endoplasmic Reticulum Stress and Oxidative Stress in Cardiovascular Diseases
}

\author{
Yan Zhou ${ }^{1,+}$, Dharmani Devi Murugan ${ }^{2,+}$, Haroon Khan ${ }^{3}$, Yu Huang ${ }^{4}$ and Wai San Cheang ${ }^{1, *(D)}$ \\ 1 State Key Laboratory of Quality Research in Chinese Medicine, Institute of Chinese Medical Sciences, \\ University of Macau, Macau 999078, China; yc07517@um.edu.mo \\ 2 Department of Pharmacology, Faculty of Medicine, University of Malaya, Kuala Lumpur 50603, Malaysia; \\ dharmani79@um.edu.my \\ 3 Department of Pharmacy, Abdul Wali Khan University, Mardan 23200, Pakistan; haroonkhn@awkum.edu.pk \\ 4 School of Biomedical Sciences, Chinese University of Hong Kong, Hong Kong 999077, China; \\ yu-huang@cuhk.edu.hk \\ * Correspondence: annacheang@um.edu.mo; Tel.: +853-8822-4914 \\ + Yan Zhou and Dharmani Devi Murugan contributed equally to this work.
}

Citation: Zhou, Y.; Murugan, D.D.; Khan, H.; Huang, Y.; Cheang, W.S Roles and Therapeutic Implications of Endoplasmic Reticulum Stress and Oxidative Stress in Cardiovascular Diseases. Antioxidants 2021, 10, 1167. https://doi.org/10.3390/ antiox10081167

Academic Editors: Pasquale Pagliaro, Tommaso Angelone, Claudia Penna, Massimo Collino and

Manuela Aragno

Received: 3 June 2021

Accepted: 21 July 2021

Published: 22 July 2021

Publisher's Note: MDPI stays neutral with regard to jurisdictional claims in published maps and institutional affiliations.

Copyright: (c) 2021 by the authors. Licensee MDPI, Basel, Switzerland. This article is an open access article distributed under the terms and conditions of the Creative Commons Attribution (CC BY) license (https:/ / creativecommons.org/licenses/by/ $4.0 /)$.

\begin{abstract}
In different pathological states that cause endoplasmic reticulum (ER) calcium depletion, altered glycosylation, nutrient deprivation, oxidative stress, DNA damage or energy perturbation/fluctuations, the protein folding process is disrupted and the ER becomes stressed. Studies in the past decade have demonstrated that ER stress is closely associated with pathogenesis of obesity, insulin resistance and type 2 diabetes. Excess nutrients and inflammatory cytokines associated with metabolic diseases can trigger or worsen ER stress. ER stress plays a critical role in the induction of endothelial dysfunction and atherosclerosis. Signaling pathways including AMP-activated protein kinase and peroxisome proliferator-activated receptor have been identified to regulate ER stress, whilst ER stress contributes to the imbalanced production between nitric oxide $(\mathrm{NO})$ and reactive oxygen species (ROS) causing oxidative stress. Several drugs or herbs have been proved to protect against cardiovascular diseases (CVD) through inhibition of ER stress and oxidative stress. The present article reviews the involvement of ER stress and oxidative stress in cardiovascular dysfunction and the potential therapeutic implications.
\end{abstract}

Keywords: endoplasmic reticulum stress; oxidative stress; cardiovascular diseases

\section{Introduction}

Endoplasmic reticulum (ER) is a crucial organelle in which protein synthesis, maturation, folding and trafficking take place. Only properly folded proteins can be destined to cellular organelles or cell surface; nevertheless, misfolded or unfolded proteins are retained in the ER to be degraded eventually [1]. Disruption of the aforementioned processes results in the accumulation of newly synthesized unfolded proteins in the ER and this condition is referred to as ER stress [2]. ER stress occurs in different pathological conditions including ischemia, hypoxia, altered glycosylation, nutrient deprivation, oxidative stress and $\mathrm{Ca}^{2+}$ depletion of ER stores, and consequently activates ER membrane-associated proteins and complex downstream signaling pathways to regulate targeted gene expression [3]. In addition, ER chaperone proteins promote the folding of other proteins, prevent protein aggregation under ER stress and maintain the normal ER function [4]. Some chaperone proteins have a positive effect on cardiovascular disease (CVD). For example, the $70 \mathrm{kDa}$ heat shock protein (Hsp70) chaperones showed cardioprotective effects in ischemia/reperfusion animal models [5], and dysregulation of glucose regulatory protein 78 (GRP78) chaperones is associated with atherosclerosis [6]. Moreover, unfolded or misfolded proteins in the ER can be degraded and quickly eliminated by the ubiquitin-proteasome system (UPS), which is called ER-Associated Degradation (ERAD). UPS and ER jointly maintain cell homeostasis and participate in the major pathways of signal transduction, cell cycle regulation and 
protein degradation [7]. Proteasome inhibitors have been shown to reduce inflammation and protect vascular function in models of atherosclerosis [8].

Oxidative stress is mainly caused by imbalanced production of reactive oxygen species (ROS) and antioxidants $[9,10]$. ROS are highly reactive chemical substances containing oxygen, controlled by the activities of specific antioxidant enzymes, such as catalase, glutathione peroxidase and superoxide dismutase [11]. The level of ROS is strictly controlled, where it is harmful at high concentrations but beneficial at low concentrations [12]. Under normal physiological conditions, the low concentrations of ROS play an important role in cell homeostasis by regulating cell signal transduction and physiological activity [13]. However, when the production of ROS exceeds the control of the antioxidant defense mechanisms, oxidative stress will occur, hindering protein folding, damaging the synthesis and accumulating toxic products, which affect the normal function of cells and lead to cell death, and ultimately may lead to diseases in the cardiovascular system $[9,14-16]$.

CVD is a common multifactorial disease $[17,18]$. CVD including hypertension, pulmonary hypertension, myocardial infarction and stroke is mainly caused by atherosclerosis; obesity and diabetes are major risk factors $[19,20]$. Studies have demonstrated that ER stress and oxidative stress play roles in the pathogenesis of these cardio-metabolic diseases. The present article reviews the involvement of ER stress and oxidative stress in cardiovascular dysfunction and the potential therapeutic implications.

\section{Regulation of ER Stress and Integration with Other Signaling Networks}

In response to ER stress, the three branches of the unfolded protein response (UPR) are activated, initiated by three ER membrane-associated proteins-PKR-like ER kinase (PERK), inositol requiring enzyme 1 (IRE1) and activating transcription factor 6 (ATF6) —and engaged complex downstream signaling pathways [2,19]. In the first branch, phosphorylated PERK phosphorylates eukaryotic initiation factor 2 on the alpha subunit (eIF2 $\alpha$ ) at Ser51 that attenuates mRNA translation. In addition, the PERK-dependent phosphorylation results in the activation of transcriptional factors: ATF4, nuclear erythroid 2-related factor 2 (Nrf2) and nuclear factor kappa-light-chain-enhancer of activated B cells (NF- $\mathrm{kB}$ ) [21,22]. In the second branch, autophosphorylated IRE1 recruits tumor necrosis factor (TNF) receptor-associated factor 2 (TRAF2) to activate Jun N-terminal kinase (JNK) and inhibitory kappa B kinase (IKK), and the downstream transcription factors activator protein 1 (AP1) and NF- $\mathrm{kB}$ [23]. Activated IRE1 also removes a 26-base intron from the mRNA of X-box binding protein 1 (XBP1). This spliced XBP1 mRNA then translates into active transcriptional factor XBP1 [24]. In the third branch, ATF6 is released and translocated to the Golgi apparatus, where it is cleaved to yield an active cytosolic ATF6 fragment acting as transcription factor [25]. The primary role of UPR is to protect the cell from ER stress by inducing the transcription of genes encoding ER chaperones and enzymes that promote protein folding, maturation, trafficking and ER-associated protein degradation so as to remove the accumulated misfolded proteins in the ER [26,27]. However, if the cell fails to clear up the protein-folding defect and restore homeostasis in the ER, the UPR will trigger apoptosis instead to eliminate the stressed cells [28].

ER stress-induced apoptosis is mediated by C/EBP homologous protein (CHOP), a transcriptional factor downstream of the PERK/eIF2 $\alpha /$ ATF4 and the ATF6 pathways [29]. Furthermore, IRE1-TRAF2 complex interacts with apoptosis signal-regulating kinase 1 (ASK1) which subsequently phosphorylates c-Jun N-terminal kinase (JNK) [30]. Both CHOP and JNK influence the apoptotic machinery by regulating the balance between pro-apoptotic and anti-apoptotic proteins from the B-cell lymphoma-2 (Bcl-2) family [31]. $\mathrm{CHOP}$ blocks the expression of anti-apoptotic Bcl-2 while it upregulates pro-apoptotic Bcl-2 homology domain 3 (BH3)-only members of the Bcl-2 family [32]. Activation of JNK phosphorylates Bcl-2, suppressing the anti-apoptotic activity of Bcl-2. JNK also phosphorylates BH3-only proteins to enhance their pro-apoptotic potential [33].

Increasing evidence shows that ER stress/UPR pathways link with other signaling networks. Pivotal inflammatory mediator, NF-KB, is activated by the IKK pathway during ER stress, inducing production of proinflammatory cytokines such as interleukin (IL)-6, IL-8, 
monocyte chemotactic protein 1 (MCP-1) and TNF- $\alpha$ [34]. ER stress also triggers activation of JNK/AP1 and induces expression of inflammatory genes. Furthermore, mitochondria forming close complex with ER through ER-associated mitochondria membranes (MAMs) are important sources of ROS [35], and thus mitochondria-derived ROS promotes ER stress [36]. Importantly, ROS is produced through the mutual redox reaction in the three organelles of mitochondria, peroxisomes and ER, known as the "Redox triangle" [37]. The accumulated ROS affects $\mathrm{Ca}^{2+}$ transfer and the protein folding function of ER stress. Mitochondrial dysfunction is aggravated by ER stress, causing massive loss of mitochondrial membrane potential, oxidative phosphorylation and other conditions [38,39]. During ER stress, a large amount of activated JNK binds to the MAM linking protein Sab and releases ROS with mitochondria [40]. The carrier protein uncoupling protein-2 (UCP-2) on mitochondria also maintains normal mitochondrial function, thus maintaining NO homeostasis and protecting the endothelial dysfunction in diabetes and obesity [41]. $\mathrm{Ca}^{2+}$ signaling molecules can tightly connect mitochondria and ER through locally inhibiting mitochondrial movement and promoting their distribution around the ER, enhancing the production of $\mathrm{Ca}^{2+}$ and ATP, thereby activating intrinsic apoptosis [42]. Furthermore, ROS enhances the formation of inflammasomes on MAMs which then induce the generation of IL-1 $\beta$ and IL-18 and the downstream inflammatory response [43]. It is also important to note that TNF $\alpha$-induced ROS accumulation causes ER stress [44].

On the other hand, ER stress is the main source of ROS and plays an important role in oxidative stress [45]. Stressed ER produces more ROS as well as fewer antioxidants due to the inhibition of protein translation via PERK/eIF2 $\alpha /$ ATF4 pathway [46]. This stress condition can be partially mitigated by the ATF4-induced antioxidant pathway involving glutathione and by activation of the Nrf2-mediated antioxidant pathway [47]. In response to oxidative stress, PERK activates the antioxidant transcription factor Nrf2 to dissociate from its inhibitor Keap-1 and transfer into the nucleus, thereby increasing intracellular glutathione levels and activating the transcription of cell defense genes [48]. ROS generation is elevated during ER stress via NADPH oxidases, mainly Nox2 and Nox4 [49]. Nox4 is mainly activated through PERK/eIF2 $\alpha$ /ATF4 and IRE1-dependent XBP1 splicing pathway. In the late stage of ER stress, the increase in the expression of ERO1 $\alpha$ induced by the transcription factor CHOP will increase the level of ROS [50]. Notably, endothelial nitric oxide synthase (eNOS), an important enzyme modulating vascular homeostasis, produces NO to protect blood vessels, and its activity is diminished by ER stress-induced apoptosis and inflammation [51], resulting in a reduction in NO bioavailability and thereby vascular dysfunction $[48,52,53]$. These results reveal the complex linkages among ER stress/UPR, oxidative stress and inflammation, modulating vascular homeostasis (Figure 1).

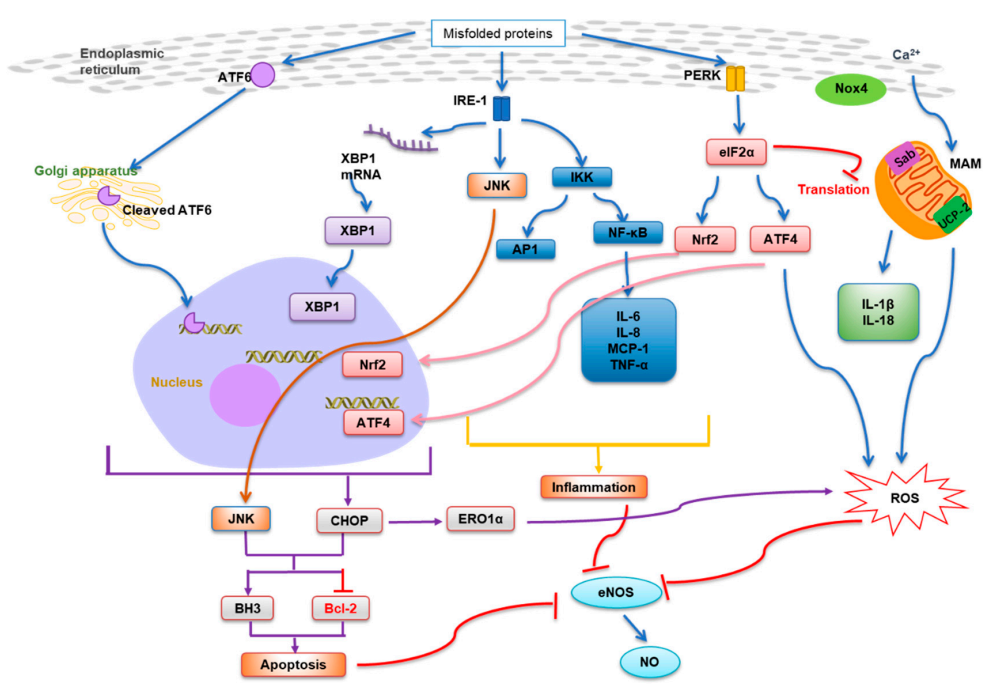

Figure 1. Schematic diagram showing regulation of endoplasmic reticulum (ER) stress and integration with other signaling networks. ER stress leads to inflammation, apoptosis, oxidative stress and reduced nitric oxide (NO) bioavailability, affecting vascular homeostasis. 


\section{ER Stress Linking to Cardiovascular Complications in Diabetes and Obesity}

Excess nutrients and inflammatory cytokines associated with metabolic diseases can trigger or worsen ER stress [54]. High glucose [55], free fatty acids (FFAs) [56], oxidized and glycated low-density lipoproteins (LDLs) [57] have been reported to induce ER stress [58]. ER stress markers PERK, IRE1 $\alpha$, ATF6 $\alpha$ and JNK are activated in obese $(o b / o b)$ mice and in mice fed a high-fat diet $[59,60]$. Chemical chaperones such as 4-phenyl butyric acid (PBA) and taurine-conjugated ursodeoxycholic acid (TUDCA) are known to alleviate ER stress. Treatment of $o b / o b$ and diabetic $(d b / d b)$ mice with PBA and TUDCA normalizes hyperglycemia, increases insulin sensitivity and reduces fatty liver disease [61]. The latest research shows that nicorandil, an approved drug for treating angina with vasodilatory property, can inhibit the PERK pathway induced by ROS-ER stress to ameliorate insulin resistance caused by high glucose [62].

Studies have suggested that $5^{\prime}$ adenosine monophosphate-activated protein kinase (AMPK) is a physiological suppressor of ER stress $[63,64]$. Apart from regulating systemic energy balance and metabolism [65], AMPK activation protects endothelial function which is attributed to inhibiting proliferation of vascular smooth muscle cells (VSMCs) and increasing nitric oxide (NO) production in endothelial cells [66,67]. Pharmacological or genetic activation of AMPK was shown to mitigate ER stress in endothelial cells and enhance endothelium-dependent relaxation in mouse aortas $[57,68]$. In addition, oxidative stress may be linked with ER stress. Inhibition of ROS production by blocking Rac1 or NADPH oxidase normalizes the elevated expression of ER stress markers and improves myocardial function in type 1 diabetic mice; a similar phenomenon is observed in diabetic retinopathy, diabetic nephropathy and atherosclerosis [69-72]. These findings suggest that ER stress and oxidative stress are potential mechanisms involved in vascular complications associated with obesity and diabetes.

Notably, AMPK subunits $\alpha 1$ and $\alpha 2$ have been reported to bind with PPAR $\delta$ to form a transcriptional complex and subsequently induce the transcription of several PPAR target genes such as uncoupling protein 3 and lipoprotein lipase [73]. Peroxisome proliferator activated receptors delta (PPAR $\delta$ ) is ubiquitously expressed, for example, in adipocytes, VSMCs and endothelial cells [74-76]. PPAR $\delta$ activation stimulates fatty acid $\beta$-oxidation in adipocytes and skeletal muscle, depletes lipid accumulation and attenuates obesity [77,78]. PPAR $\delta$ also regulates glucose homeostasis $[79,80]$, as well as protects against atherosclerosis [81] and endothelial dysfunction [82-84].

A widely used anti-diabetic drug metformin improves insulin sensitivity and glucose homeostasis, and at the same time reduces endothelial dysfunction $[85,86]$ and thereby cardiovascular risks in diabetic patients [87]. Metformin is well known to activate AMPK in different tissues in humans and rodents [88-90]. The effects of metformin on endothelial function are largely mediated through AMPK and PPAR $\delta$ with a subsequent alleviation of ER stress and oxidative stress as well as increased eNOS activity and NO production, highlighting the central role of PPAR $\delta$ downstream of AMPK activation to combat against diabetes- and obesity-related vasculopathy, inflammation and hypertension [91-93]. Likewise, exercise is known to activate AMPK and is found to ameliorate ER stress and endothelial dysfunction in diabetes through PPAR $\delta$ [94]. These findings imply a close linkage between ER stress and vascular dysfunction in diabetes modulated by AMPK and PPARס.

Evidence shows that ER stress contributes to endothelial cell inflammatory responses and apoptosis in diabetic retinopathy $[95,96]$. In streptozotocin (STZ)-induced type 1 diabetic mice, retinal inflammation and vascular leakage are attributed to ATF4 activation of STAT3 $[97,98]$. In addition, elevated epidermal growth factor receptor tyrosine kinase (EGFR-TK) phosphorylation activates PERK/eIF2 $\alpha /$ ATF4 branch and contributes to microvascular dysfunction as well as cardiac fibrosis in the STZ model [99,100]. Treating STZ mice with EGFR-TK inhibitor (AG1478) and ER stress alleviator (TUDCA) augments endothelium-dependent relaxation and reverse the augmented Nox2 and Nox4 in mesenteric resistance arteries [101]. Importantly, TUDCA treatment exerts protective effects on 
hind-limb ischemia coupled with reduced body weight, blood glucose and insulin level in type 2 diabetic $d b / d b$ mice [102]. These suggest that ER stress plays a role in ischemiainduced neovascularization associated with diabetes and is involved in regulating obesity and insulin resistance.

Mangiferin, a widely used Chinese herb for treating diabetes mellitus, has been shown to inhibit ER stress and the associated oxidative stress, TXNIP expression, NLRP3 inflammasome activation, production of IL- $1 \beta$ and IL- 6 whilst increasing NO release in endothelial cells exposed to high glucose $[103,104]$. In addition, physical exercise has been shown to have vasoprotective effect, activating PPAR $\delta$ to improve vascular endothelial function in diabetic and obese mouse models [94].

\section{ER Stress in Atherosclerosis}

In line with the in vitro results that high glucose induces ER stress markers and accompanied endothelial dysfunction [55,105], FFAs [56], oxidized and glycated LDLs [57], ER stress has been reported to be activated at athero-susceptible arterial regions [106] in obese $(o b / o b)$ mice and in mice fed a high-fat diet [59]. On the other hand, reduction in AMPK $\alpha 2$ expression increases the ER stress and atherosclerosis [107].

In view of the high prevalence of obesity clustering with type 2 diabetes and CVD, the detailed mechanisms of its pathogenesis and effective therapeutic approaches are important to explore nowadays. In contrast to proinflammatory effects of oxidized LDLs (oxLDLs), high-density lipoproteins (HDLs) have anti-inflammatory and antioxidant effects and they can prevent ER stress and autophagy induced by oxLDL [108-110].

IRE1 inhibitors STF-083010 and $4 \mu 8 \mathrm{C}$ suppress lipid-triggered mitochondrial ROS release, NLRP3 inflammasome activation, production of IL-1 and IL-18 and thus retarding the progression of atherosclerosis in $\mathrm{ApoE}^{-/-}$mice [111].

Some natural compounds have also been shown to inhibit ER stress, implying a protective role in atherosclerosis. Kaempferol acts on caspase- 3 and caspase- 7 and downregulates the expression of GRP78 and CHOP to prevent cell death [112]. Atrovastatin inhibits ER stress through AMPK activation in human endothelial cells and in atherosclerotic mice [113]. In addition to natural compounds, exercise has been shown to attenuate ER stress, thereby ameliorating atherosclerotic vascular dysfunction by reversing the increase in the expression of $\mathrm{CHOP}$ in atherosclerotic mice and increasing the expression of downstream signaling pathways, including eNOS, UCP-2 and caspase-1 [114].

\section{Hypertension}

ER stress has been strongly implicated in the pathogenesis of hypertension, involving diverse cardioregulatory systems including brain, pulmonary and systemic vasculature and heart $[45,115]$. ER stress in brain has been implicated in the angiotensin II (Ang II)-induced hypertension which can be reversed by treatment with TUDCA [116]. CNS selective administration of TUDCA globally reduces brain ER stress and rescues obesity-induced hypertension [117]. Infusion of Ang II in mice induced the UPR proteins BiP and CHOP in aortas, mesenteric arteries and myocardium [118]. The same group demonstrated that both TUDCA and 4-PBA normalize blood pressure, reduce cardiomyocyte UPR activity and cardiac fibrosis and restore macrovascular endothelial function via inhibition of transforming growth factor-beta 1 (TGF- $\beta 1$ ), confirming a key pathogenic role for ER stress in hypertension [118]. Similar results were obtained in hypertensive rats whereby ER stress inhibition by 4-PBA and TUDCA normalized blood pressure by suppressing $\mathrm{Ca}^{2+}$-dependent cytosolic phospholipase A2 (cPLA2)/cyclooxygenase (COX) pathway [119]. Additional work has also shown an improved vascular function with decreased Ang II-induced vascular ER stress [120-123]. These studies showed that inhibition of ER stress is partially attributed to the decrease in Ang II-mediated markers of oxidative stress such as nitrotyrosine, NOX 2 and NOX4. It is likely that during hypertensive disease, vascular oxidative and ER stress are bi-directionally related. Furthermore, Takayanagi et al. demonstrated that inhibition 
of metalloproteinase domain 17 (ADAM17) activation contributes to the diminished Ang II-induced ER stress [124].

\section{Pulmonary Arterial Hypertension}

Pulmonary arterial hypertension (PAH) is related to excessive pulmonary vasoconstriction and abnormal vascular remodeling. Previous studies showed that ER stress causes vascular pathological changes and thus participates in the occurrence and development of PAH [125]. Research targeting ER stress in PAH has focused on pulmonary artery smooth muscle cells (PASMC), as exaggerated proliferation and resistance to apoptosis of PASMCs is a key component of vascular remodeling [126]. ER stress has been found to be activated in the vasculature of mice with hypoxia-induced PAH [127], and administration of 4-PBA significantly reduces pulmonary hypertension, arterial remodeling and right ventricular hypertrophy [128-130]. Besides the known chemical chaperones, hydrogen sulfide [115], intermedin [131] and 4u8c, an inhibitor of the IRE1 $\alpha /$ XBP1 pathway [132], have been shown to restrain hypoxia-induced cell proliferation and migration and reverse hypoxia-induced apoptosis arrest, which correlated with the suppressed expression of UPR markers. In 2011, Sutendra et al. found that the lack of Nogo-B in PASMCs from Nogo-A/B-deficient mice prevents hypoxia-induced changes in vitro and in vivo, resulting in complete resistance to induction of PAH [133]. Nogo is a member of the reticulon family of proteins that regulates the tubular structure of the ER and is implicated in vascular remodeling and PAH. The elevated levels of Nogo-B during ER stress lead to restructuring and disruption of the mitochondria-ER unit, which eventually suppress apoptosis; thus, targeting Nogo-B can be a potential selective therapeutic strategy against PAH $[133,134]$. Of note, mice with conditional deletion of GATA-6, a member of the GATA family of zinc-finger transcription factors, in endothelial cells display an elevation of ER stress markers and worsening of hypoxia-induced PAH $[135,136]$. This result reveals that endothelial cells play a critical role in triggering ER stress in hypoxic mice. In peripheral blood mononuclear cells isolated from patients with limited cutaneous systemic sclerosis and PAH, ER stress markers are upregulated and in positive correlation with IL-6 level and severity of pulmonary artery pressure [137].

\section{Hyperhomocysteinemia}

Homocysteine (Hcy) is well known to induce ER stress [138]. High plasma level of Hcy represents an independent risk factor for CVD $[139,140]$. Hcy induces cell death of vascular endothelial cells by activation of JNK and ATF3 through IRE1/TRAF2 pathway [141] and by eIF2 $\alpha$ induction of the T-cell death associated gene 51 (TDAG51) [142] which contributes to the development of atherosclerosis. Hcy-induced ER stress is also shown to impair NO production and calcium-activated potassium channels $\left(\mathrm{IK}_{\mathrm{Ca}}\right.$ and $\left.\mathrm{SK}_{\mathrm{Ca}}\right)$ [143] and increase NOX-generated ROS [50] to reduce vasorelaxation. In addition, Hcy was shown to target soluble epoxide hydrolase (sEH), a major enzyme that hydrolyzes epoxyeicosatrienoic acids and attenuates their cardiovascular protective effects [144]. Treatment of cultured human endothelial cells with Hcy upregulates sEH levels, which is associated with the up-regulation of adhesion molecules and activation of ATF6 $[145,146]$. Besides Hcy, homocysteine thiolactone was also shown to upregulate GRP78 expression and induce ER stress, leading to a downstream enhancement of oxidative stress and inflammation, which finally cause vascular endothelial dysfunction [147]. Overall, Hcy-induced ER stress and oxidative stress are reciprocally associated.

Hyperhomocysteinemia (HHcy) is associated with hypertension. Alleviation of ER stress by black tea consumption was found to ameliorate vascular dysfunction and normalize plasma Hcy level and blood pressure in hypertensive rats [120]. Enalapril, an antihypertensive agent, was shown to protect endothelial cells and improve hypertension through inhibiting ER stress, as well [148]. Piceatannol, a resveratrol analogue, protected endothelial cells against Hcy-induced apoptosis, oxidative stress and ER stress via Nrf2dependent expression of heme oxygenase 1 [149]. In hyperhomocysteinemic mice, ator- 
vastatin improved atherosclerotic plaque stability by inhibiting ER stress [150] and this protective effect may involve activation of AMPK [151]. Moreover, salidroside protects against HHcy-induced endothelial dysfunction by down-regulating Bip and CHOP expression and decreasing PERK and IRE1 $\alpha$ phosphorylation [152]. Alpha-lipoic acid ameliorates Hcy-induced ER stress and oxidative stress, thus reducing apoptosis and inflammation in human aortic endothelial cells [153]. The glucagon-like peptide 1 (GLP-1) analogue exendin-4 activates AMPK, inhibits ER stress and superoxide anion production, thereby ameliorating HHcy-induced endothelial dysfunction [154]. These findings suggest that targeting Hcy-induced ER stress is a potential therapeutic strategy for treating CVD.

\section{Myocardial Infarction}

Left ventricular remodeling after myocardial infarction (MI) is a key factor in heart failure [155]. MI activates JNK through the IRE1/TRAF2 pathway, showing high levels of JNK phosphorylation [156]. ASK1 plays an important role in ER stress-induced apoptosis [157]. Deletion of ASK1 attenuates left ventricular remodeling, implying that ER stress contributes to myocyte loss during MI [158]. MI activates mitogen-activated protein kinase (MAPK) through induction of ER stress, and NFKB pathway in hypoxic cardiac cells or cardiac infarct tissues [159]. In the MI mouse model induced by left anterior descending (LAD) ligation, the expression of inflammatory cytokines in the heart increased, such as TNF $\alpha$, IL-1, IL-6 and MCP-1 [160]. In addition, the expression of Bax and cleaved caspase 3 also elevated, while the expression of $\mathrm{Bcl}-2$ diminished in the treated mice. MI can induce oxidative stress, leading to increased ROS accumulation in hypoxic cardiac cells and the elevated activity of NADPH oxidase [161].

Zinc finger protein ZBTB20 has an anti-apoptotic effect and can relieve heart remodeling after MI. ZBTB20 protects the heart by reducing the expression of TNF $\alpha$, inhibiting ASK1 and JNK signal transduction, and also suppressing the activity of NADPH oxidase [161]. Valsartan improves myocardial remodeling by inhibiting ASK1-dependent signaling pathway [162]. Panax notoginseng flower (PN-F) is widely used to treat CVD by increasing expression of genes including hypoxia inducible factor 1 (HIF-1), vascular endothelial growth factor- $\alpha$ (VEGFA) and kinase insert domain receptor (KDR), and upregulating the expression of Bcl-2 and Bax to inhibit cell apoptosis and promote angiogenesis in the infarct area [163]. Furthermore, exercise can be used as an adjuvant treatment for heart failure, thereby improving CVD by increasing the activity of the anti-aging molecule Sirt 1 [164]. All this evidence supports the interaction among ER stress, oxidative stress and inflammation contributing to $\mathrm{MI}$ and the potential therapeutic implications such as using valsartan, natural plants (PN-F) and exercise.

\section{Stroke}

In the case of stroke, ER stress-associated apoptosis is induced and leads to neuronal cell death, which can be prevented in CHOP-deficient mice [165]. Stroke induces IRE1 and PERK to enhance the expression of GRP78 and CHOP through ER stress to promote cell apoptosis [166]. Ischemic stroke is the most common type of stroke and the disease with the most serious sequelae [167]. A recent study shows that Hes1 knockdown induces cell apoptosis through ER stress, which can increase cerebral infarction and aggravate ischemic stroke. Hes1-induced ER stress can exacerbate the disease by activating the PERK/CHOP signaling pathway [168]. Taurine has been shown to inhibit the pathways of ATF6 and IRE1 and limits ROS-induced ER stress in rat stroke model [169]. Apelin-36 protects neurons from apoptosis and activates caspase- 3 by inhibiting the activation of ER stress and UPR and the increase in CHOP/GRP78, thereby reducing infarction and cell apoptosis caused by ischemic stroke [170]. The basic fibroblast growth factor (bFGF) can improve ischemic oxidative damage by inhibiting ER stress response proteins including CHOP and ATF6. In addition, bFGF achieves neuroprotective effects by activating PI3K/Akt and ERK1/2 pathways [171]. 


\section{ER Stress as Drug Target to Combat against CVD}

Given the evidence that ER stress is widely associated with CVD, pharmacological modulation to manipulate ER stress/UPR signaling becomes a growing consensus to treat diverse vascular disorders [172]. Approaches to prolong the adaptive phases of the UPR to enhance cell survival and recovery or to inhibit ER stress-associated apoptosis may be beneficial in combating against a range of human diseases [173]. For instance, salubrinal was found to inhibit eIF2 $\alpha$ dephosphorylation and thus favors cell survival under ER stress [174]. FDA-approved $26 \mathrm{~S}$ proteasome inhibitors, bortezomib and carfilzomib induce ER stress and cell death in multiple myeloma cells and are used for the treatment of multiple myeloma [175]. On the other hand, 4-phenylbutryic acid (PBA) and taurine-conjugated ursodeoxycholic acid (TUDCA) are shown to attenuate ER stress and disease symptoms in animal models. PBA and TUDCA are FDA-approved chemical chaperones for clinical use in urea cycle disorders and in cystic fibrosis, respectively. Oral administration of PBA and TUDCA ameliorates glucose homeostasis and defects in pancreatic $\beta$ cells in diabetic muse models $[61,176]$. More importantly, both chemical chaperones ameliorate insulin resistance in human obese subjects $[177,178]$. Another chemical chaperone SRT1720 reduces ER stress, apoptosis and inflammation induced by glucosamine in HUVECs through the regulation of raptor acetylation [179]. Importantly, the drugs approved to treat hypertension, obesity and diabetes including enalapril, valsartan, atorvastatin, metformin and exendin-4, as well as herbal medicine or natural plants such as mangiferin, black tea and Panax notoginseng flower, have been demonstrated to possess vasoprotective effects through inhibiting ER stress and oxidative stress. Besides natural compounds, physical activity and exercise-based cardiac rehabilitation are effective to suppress oxidative stress and thus improve endothelial function. Exercise improves vascular function by regulating the balance between $\mathrm{NO}$ and ROS. Some key mediators of motor regulation may provide a potential effective target for the treatment of CVD. These studies suggest the therapeutic potential of targeting ER stress to treat human disease. In regard to the cross-wired networking of the UPR/ER stress pathways with other signaling networks, multiple nodes should be targeted simultaneously to achieve desired benefits.

\section{Conclusions and Perspectives}

Taken all together, increasing evidence indicates the crucial role of endoplasmic reticulum (ER) stress in vascular dysfunction. It is likely that occurrence of ER stress contributes to the reduced nitric oxide (NO) bioavailability and thereby vascular dysfunction through oxidative stress- and inflammation-dependent mechanisms. In addition, many drugs or herbs for the treatment of cardiovascular disease (CVD) have been studied (Table 1), but the specific pharmacological activity and the mechanism(s) of action of these drugs, as well as the pathological changes that affect human diseases, need to be further investigated. A better understanding of the cellular interactions of unfolded protein response (UPR)/ER stress and other specific pathways in different vascular beds contributing to pathogenic conditions will contribute to developing new therapies to overcome CVD.

Table 1. Drugs or herbs affecting endoplasmic reticulum stress to ameliorate cardiovascular diseases.

\begin{tabular}{|c|c|c|c|}
\hline Drugs or Herbs & Action Mechanism & Cardiovascular Disease & References \\
\hline 4-phenyl butyric acid (PBA) & $\begin{array}{l}\uparrow \text { insulin sensitivity; } \downarrow \text { blood pressure, } \\
\text { fatty liver disease, cardiomyocyte UPR } \\
\text { activity, cardiac fibrosis, TGF- } \beta 1 \text {, } \\
\text { cPLA2/COX, arterial remodeling, right } \\
\text { ventricular hypertrophy. }\end{array}$ & $\begin{array}{l}\text { Diabetes and obesity, } \\
\text { hypertension, pulmonary } \\
\text { arterial hypertension }\end{array}$ & {$[61,118,119,128-130]$} \\
\hline $\begin{array}{l}\text { taurine-conjugated } \\
\text { ursodeoxycholic acid } \\
\text { (TUDCA) }\end{array}$ & $\begin{array}{l}\uparrow \text { insulin sensitivity, } \\
\text { endothelium-dependent relaxation; } \downarrow \\
\text { blood pressure, fatty liver disease, } \\
\text { cardiomyocyte UPR activity, cardiac } \\
\text { fibrosis, TGF- } \beta 1 \text {, cPLA2/COX, Nox2, } \\
\text { Nox4, body weight. }\end{array}$ & $\begin{array}{l}\text { Diabetic vasculopathy, } \\
\text { diabetic retinopathy, } \\
\text { hypertension }\end{array}$ & {$[61,118,119,128-130]$} \\
\hline
\end{tabular}


Table 1. Cont.

\begin{tabular}{|c|c|c|c|}
\hline Drugs or Herbs & Action Mechanism & Cardiovascular Disease & References \\
\hline Metformin & $\begin{array}{c}\uparrow \text { AMPK, PPAR } \delta, \text { eNOS activity, NO } \\
\text { production; } \downarrow \text { ER stress, } \\
\text { oxidative stress. }\end{array}$ & Diabetic vasculopathy & [91-93] \\
\hline AG1478 & $\begin{array}{l}\uparrow \text { endothelium-dependent relaxation; } \\
\qquad \text { Nox2, Nox4. }\end{array}$ & Diabetic retinopathy & [101] \\
\hline Mangiferin & $\begin{array}{c}\uparrow \text { TXNIP, NLRP3 inflammasome, IL-1 } \beta, \\
\text { IL-6, NO. }\end{array}$ & Diabetic vasculopathy & [103] \\
\hline nicorandil & $\uparrow$ insulin resistance; $\downarrow$ PERK inhibition. & Diabetes & {$[62]$} \\
\hline Kaempferol & $\uparrow$ caspase- 3 , caspase-7; $\downarrow$ GRP78, CHOP. & Atherosclerosis & [112] \\
\hline Atrovastatin & $\uparrow \mathrm{AMPK}$. & Atherosclerosis & [113] \\
\hline hydrogen sulfide & chemical chaperones. & $\begin{array}{l}\text { Pulmonary arterial } \\
\text { hypertension }\end{array}$ & [115] \\
\hline intermedin & chemical chaperones. & $\begin{array}{c}\text { Pulmonary arterial } \\
\text { hypertension }\end{array}$ & [131] \\
\hline $4 u 8 c$ & $\begin{array}{c}\text { chemical chaperones; } \\
\downarrow \text { IRE1 } \alpha / \text { XBP1 inhibition. }\end{array}$ & $\begin{array}{l}\text { Pulmonary arterial } \\
\text { hypertension }\end{array}$ & [132] \\
\hline black tea & $\begin{array}{l}\downarrow \text { ER stress, oxidative stress, blood } \\
\text { pressure, endothelial dysfunction. }\end{array}$ & Hyperhomocysteinemia & [120] \\
\hline Enalapril & $\downarrow$ ER stress, blood pressure. & Hyperhomocysteinemia & [148] \\
\hline Piceatannol & $\downarrow$ apoptosis, oxidative stress, ER stress. & Hyperhomocysteinemia & [149] \\
\hline Atorvastatin & $\uparrow \mathrm{AMPK} ; \downarrow$ ER stress. & Hyperhomocysteinemia & {$[150,151]$} \\
\hline salidroside & $\begin{array}{l}\downarrow \text { Bip, CHOP, PERK phosphorylation, } \\
\text { IRE1 } \alpha \text { phosphorylation. }\end{array}$ & Hyperhomocysteinemia & [152] \\
\hline Alpha-lipoic acid & $\begin{array}{l}\downarrow \text { ER stress, oxidative stress, } \\
\text { apoptosis, inflammation. }\end{array}$ & Hyperhomocysteinemia & [153] \\
\hline Exendin-4 & $\begin{array}{c}\uparrow \text { AMPK; } \downarrow \text { ER stress, superoxide } \\
\text { anion production. }\end{array}$ & Hyperhomocysteinemia & [154]. \\
\hline Zinc finger protein ZBTB20 & $\downarrow \mathrm{TNF} \alpha$, ASK1, JNK, NADPH oxidase. & Myocardial infarction & [161] \\
\hline Valsartan & $\downarrow$ ASK1. & Myocardial infarction & [162] \\
\hline Panax notoginseng flower & 个 HIF-1, VEGFA, KDR, Bcl-2, Bax. & Myocardial infarction & [163] \\
\hline Taurine & $\downarrow$ TF-6 and IRE-1. & Stroke & [169] \\
\hline Apelin-36 & $\downarrow$ CHOP/GRP78. & Stroke & [170] \\
\hline Basic fibroblast growth factor & $\uparrow$ PI3K/Akt, ERK1/2; $\downarrow$ CHOP, ATF6. & Stroke & {$[171]$} \\
\hline
\end{tabular}

Author Contributions: Writing—original draft preparation, Y.Z. and D.D.M.; writing-review and editing, H.K., Y.H. and W.S.C.; supervision, W.S.C. All authors have read and agreed to the published version of the manuscript.

Funding: This research was funded by the Research Committee of the University of Macau (SRG201900154-ICMS and MYRG2019-00157-ICMS), the Operation Fund of State Key Laboratory of Quality Research in Chinese Medicine of University of Macau (SKL-QRCM(UM)-2020-2022) and Hong Kong RGCSenior Research Fellow Scheme (SRFS2021-4S04). The APC was funded by MYRG2019-00157-ICMS.

Institutional Review Board Statement: Not applicable.

Informed Consent Statement: Not applicable.

Acknowledgments: The authors thank the technical team of Institute of Chinese Medical Sciences in University of Macau for their valuable assistance. 
Conflicts of Interest: The authors declare no conflict of interest.

\section{References}

1. Gething, M.J.; Sambrook, J. Protein folding in the cell. Nature 1992, 355, 33-45. [CrossRef]

2. Hotamisligil, G.S. Endoplasmic reticulum stress and the inflammatory basis of metabolic disease. Cell 2010, 140, 900-917. [CrossRef] [PubMed]

3. Ma, Y.; Hendershot, L.M. ER chaperone functions during normal and stress conditions. J. Chem. Neuroanat. 2004, $28,51-65$. [CrossRef] [PubMed]

4. Benjamin, I.J.; McMillan, D.R. Stress (heat shock) proteins: Molecular chaperones in cardiovascular biology and disease. Circ. Res. 1998, 83, 117-132. [CrossRef] [PubMed]

5. Liu, X.; Engelman, R.M.; Moraru, I.I.; Rousou, J.A.; Flack, J.E., III; Deaton, D.W.; Maulik, N.; Das, D.K. Heat shock. A new approach for myocardial preservation in cardiac surgery. Circulation 1992, 86, II358-II363. [PubMed]

6. Quinones, Q.J.; de Ridder, G.G.; Pizzo, S.V. GRP78: A chaperone with diverse roles beyond the endoplasmic reticulum. Histol. Histopathol. 2008, 23, 1409-1416.

7. Lord, J.M.; Davey, J.; Frigerio, L.; Roberts, L.M. Endoplasmic reticulum-associated protein degradation. Semin. Cell Dev. Biol. 2000, 11, 159-164. [CrossRef]

8. Demasi, M.; Laurindo, F.R. Physiological and pathological role of the ubiquitin-proteasome system in the vascular smooth muscle cell. Cardiovasc. Res. 2012, 95, 183-193. [CrossRef]

9. Dhawan, V.; Bakshi, C.; Rather, R.A. Molecular Targets and Novel Therapeutics to Target Oxidative Stress in Cardiovascular Diseases. In Oxidative Stress in Heart Diseases; Chakraborti, S., Dhalla, N., Ganguly, N., Dikshit, M., Eds.; Springer: Singapore, 2019; pp. 59-82.

10. Dubois-Deruy, E.; Peugnet, V.; Turkieh, A.; Pinet, F. Oxidative Stress in Cardiovascular Diseases. Antioxidant 2020, 9, 864. [CrossRef] [PubMed]

11. D’Oria, R.; Schipani, R.; Leonardini, A.; Natalicchio, A.; Perrini, S.; Cignarelli, A.; Laviola, L.; Giorgino, F. The Role of Oxidative Stress in Cardiac Disease: From Physiological Response to Injury Factor. Oxid. Med. Cell. Longev. 2020, 2020, 5732956. [CrossRef]

12. Leopold, J.A.; Loscalzo, J. Oxidative mechanisms and atherothrombotic cardiovascular disease. Drug Discov. Today Strat. 2008, 5, 5-13. [CrossRef] [PubMed]

13. Sachidanandam, K.; Fagan, S.C.; Ergul, A. Oxidative stress and cardiovascular disease: Antioxidants and unresolved issues. Cardiovasc. Drug Rev. 2005, 23, 115-132. [CrossRef] [PubMed]

14. Papaconstantinou, J. The Role of Signaling Pathways of Inflammation and Oxidative Stress in Development of Senescence and Aging Phenotypes in Cardiovascular Disease. Cells 2019, 8, 1383. [CrossRef] [PubMed]

15. Garcia, N.; Zazueta, C.; Aguilera-Aguirre, L. Oxidative Stress and Inflammation in Cardiovascular Disease. Oxid. Med. Cell. Longev. 2017, 2017, 5853238. [CrossRef]

16. Xu, T.; Ding, W.; Ji, X.; Ao, X.; Liu, Y.; Yu, W.; Wang, J. Oxidative Stress in Cell Death and Cardiovascular Diseases. Oxid. Med. Cell. Longev 2019, 2019, 9030563. [CrossRef]

17. Pickering, R.J. Oxidative Stress and Inflammation in Cardiovascular Diseases. Antioxidant 2021, 10, 171. [CrossRef] [PubMed]

18. Du, X.; Patel, A.; Anderson, C.S.; Dong, J.; Ma, C. Epidemiology of Cardiovascular Disease in China and Opportunities for Improvement: JACC International. J. Am. Coll. Cardiol. 2019, 73, 3135-3147. [CrossRef]

19. Zhang, K.; Kaufman, R.J. From endoplasmic-reticulum stress to the inflammatory response. Nature 2008, 454, 455-462. [CrossRef]

20. Lu, J.; Zhang, L.; Lu, Y.; Su, M.; Li, X.; Liu, J.; Zhang, H.; Nasir, K.; Masoudi, F.A.; Krumholz, H.M.; et al. Secondary prevention of cardiovascular disease in China. Heart 2020, 106, 1349-1356. [CrossRef]

21. Koopman, M.; Hetz, C.; Nollen, E.A.A. Saved by the Matrix: UPR Independent Survival under ER Stress. Cell 2019, 179, 1246-1248. [CrossRef]

22. Kopp, M.C.; Larburu, N.; Durairaj, V.; Adams, C.J.; Ali, M.M.U. UPR proteins IRE1 and PERK switch BiP from chaperone to ER stress sensor. Nat. Struct. Mol. Biol. 2019, 26, 1053-1062. [CrossRef] [PubMed]

23. Minamino, T.; Kitakaze, M. ER stress in cardiovascular disease. J. Mol. Cell. Cardiol. 2010, 48, 1105-1110. [CrossRef]

24. Xu, W.; Wang, C.; Hua, J. X-box binding protein 1 (XBP1) function in diseases. Cell Biol. Int. 2021, 45, 731-739. [CrossRef] [PubMed]

25. Kubra, K.T.; Akhter, M.S.; Uddin, M.A.; Barabutis, N. Unfolded protein response in cardiovascular disease. Cell. Signal. 2020, 73, 109699. [CrossRef] [PubMed]

26. Zhang, G.; Wang, X.; Gillette, T.G.; Deng, Y.; Wang, Z.V. Unfolded Protein Response as a Therapeutic Target in Cardiovascular Disease. Curr. Top. Med. Chem. 2019, 19, 1902-1917. [CrossRef]

27. Zhu, Q. The ER stress-autophagy axis: Implications for cognitive dysfunction in diabetes mellitus. Clin. Sci. (Lond.) 2020, 134, 1255-1258. [CrossRef] [PubMed]

28. Hosseini, M.; Shaygannia, E.; Rahmani, M.; Eskandari, A.; Golsefid, A.A.; Tavalaee, M.; Gharagozloo, P.; Drevet, J.R.; NasrEsfahani, M.H. Endoplasmic Reticulum Stress (ER Stress) and Unfolded Protein Response (UPR) Occur in a Rat Varicocele Testis Model. Oxid. Med. Cell. Longev. 2020, 2020, 5909306. [CrossRef] [PubMed] 
29. Danecka, M.D.; Jurczak, W.; Olszanecka, A.; Krawczyk, K.; Skotnicki, A.B. Primary cardioprotection in lymphoma patients with high risk of cardiovascular disease, treated with (R) CHOP regimen: A single center retrospective analysis. J. Clin. Oncol. 2015, 33, e19515. [CrossRef]

30. Yang, Y.; Liu, Y.; Zhang, Y.; Ji, W.; Wang, L.; Lee, S.C. Periplogenin Activates ROS-ER Stress Pathway to Trigger Apoptosis via BIP-eIF2alpha- CHOP and IRE1alpha-ASK1-JNK Signaling Routes. Anticancer Agents Med. Chem. 2021, 21, 61-70. [CrossRef]

31. Craige, S.M.; Chen, K.; Blanton, R.M.; Keaney, J.F.; Kant, S. JNK and cardiometabolic dysfunction. Biosci. Rep. 2019, 39, BSR20190267. [CrossRef] [PubMed]

32. Li, F.Z.; Ling, X.; Cao, S.S.; Cheng, Q.Y. Discovery and characterization of a small chemical compound that shows exceptional antitumor activity and targets multiple antiapoptotic proteins in the inhibitor of apoptosis (IAP) and Bcl-2 families. Cancer Res. 2011, 71, 4525.

33. Li, G.; Qi, W.Q.; Li, X.X.; Zhao, J.W.; Luo, M.H.; Chen, J.J. Recent Advances in c-Jun N-Terminal Kinase (JNK) Inhibitors. Curr. Med. Chem. 2021, 28, 607-627. [CrossRef]

34. Garg, A.D.; Kaczmarek, A.; Krysko, O.; Vandenabeele, P.; Krysko, D.V.; Agostinis, P. ER stress-induced inflammation: Does it aid or impede disease progression? Trends Mol. Med. 2012, 18, 589-598. [CrossRef] [PubMed]

35. Marchi, S.; Patergnani, S.; Pinton, P. The endoplasmic reticulum-mitochondria connection: One touch, multiple functions. Bioenergetics 2014, 1837, 461-469. [CrossRef] [PubMed]

36. Peoples, J.N.; Saraf, A.; Ghazal, N.; Pham, T.T.; Kwong, J.Q. Mitochondrial dysfunction and oxidative stress in heart disease. Exp. Mol. Med. 2019, 51, 1-13. [CrossRef] [PubMed]

37. Yoboue, E.D.; Sitia, R.; Simmen, T. Redox crosstalk at endoplasmic reticulum (ER) membrane contact sites (MCS) uses toxic waste to deliver messages. Cell Death Dis. 2018, 9, 331. [CrossRef]

38. Murphy, M.P. How mitochondria produce reactive oxygen species. Biochem. J. 2009, 417, 1-13. [CrossRef] [PubMed]

39. Thoma, A.; Lyon, M.; Al-Shanti, N.; Nye, G.A.; Cooper, R.G.; Lightfoot, A.P. Eukarion-134 Attenuates Endoplasmic Reticulum Stress-Induced Mitochondrial Dysfunction in Human Skeletal Muscle Cells. Antioxidant 2020, 9, 710. [CrossRef] [PubMed]

40. Win, S.; Than, T.A.; Fernandez-Checa, J.C.; Kaplowitz, N. JNK interaction with Sab mediates ER stress induced inhibition of mitochondrial respiration and cell death. Cell Death Dis. 2014, 5, e989. [CrossRef] [PubMed]

41. Tian, X.Y.; Wong, W.T.; Xu, A.; Lu, Y.; Zhang, Y.; Wang, L.; Cheang, W.S.; Wang, Y.; Yao, X.; Huang, Y. Uncoupling protein-2 protects endothelial function in diet-induced obese mice. Circ. Res. 2012, 110, 1211-1216. [CrossRef]

42. Bravo, R.; Vicencio, J.M.; Parra, V.; Troncoso, R.; Munoz, J.P.; Bui, M.; Quiroga, C.; Rodriguez, A.E.; Verdejo, H.E.; Ferreira, J.; et al. Increased ER-mitochondrial coupling promotes mitochondrial respiration and bioenergetics during early phases of ER stress. $J$. Cell Sci. 2011, 124, 2143-2152. [CrossRef] [PubMed]

43. Van Vliet, A.R.; Verfaillie, T.; Agostinis, P. New functions of mitochondria associated membranes in cellular signaling. Biochim. Biophys. Acta 2014, 1843, 2253-2262. [CrossRef] [PubMed]

44. Xue, X.; Piao, J.H.; Nakajima, A.; Sakon-Komazawa, S.; Kojima, Y.; Mori, K.; Yagita, H.; Okumura, K.; Harding, H.; Nakano, $\mathrm{H}$. Tumor necrosis factor alpha (TNFalpha) induces the unfolded protein response (UPR) in a reactive oxygen species (ROS)dependent fashion, and the UPR counteracts ROS accumulation by TNFalpha. J. Biol. Chem. 2005, 280, 33917-33925. [CrossRef]

45. Chen, T.; Zhu, J.; Wang, Y.H.; Hang, C.H. ROS-Mediated Mitochondrial Dysfunction and ER Stress Contribute to CompressionInduced Neuronal Injury. Neuroscience 2019, 416, 268-280. [CrossRef]

46. Liu, C.; Zhang, A. ROS-mediated PERK-eIF2alpha-ATF4 pathway plays an important role in arsenite-induced L-02 cells apoptosis via regulating CHOP-DR5 signaling. Environ. Toxicol. 2020, 35, 1100-1113. [CrossRef] [PubMed]

47. Digaleh, H.; Kiaei, M.; Khodagholi, F. Nrf2 and Nrf1 signaling and ER stress crosstalk: Implication for proteasomal degradation and autophagy. Cell. Mol. Life Sci. 2013, 70, 4681-4694. [CrossRef]

48. Ooi, B.K.; Goh, B.H.; Yap, W.H. Oxidative Stress in Cardiovascular Diseases: Involvement of Nrf2 Antioxidant Redox Signaling in Macrophage Foam Cells Formation. Int. J. Mol. Sci. 2017, 18, 2336. [CrossRef] [PubMed]

49. Santos, C.X.; Nabeebaccus, A.A.; Shah, A.M.; Camargo, L.L.; Filho, S.V.; Lopes, L.R. Endoplasmic reticulum stress and Noxmediated reactive oxygen species signaling in the peripheral vasculature: Potential role in hypertension. Antioxid. Redox Signal. 2014, 20, 121-134. [CrossRef]

50. Ochoa, C.D.; Wu, R.F.; Terada, L.S. ROS signaling and ER stress in cardiovascular disease. Mol. Asp. Med. 2018, 63, 18-29. [CrossRef]

51. Wood, S.K. The role of inflammation and oxidative stress in depression and cardiovascular disease. In Cardiovascular Implications of Stress and Depression; Chantler, P.D., Larkin, K.T., Eds.; Academic Press: London, UK, 2020; pp. 175-209.

52. Senoner, T.; Dichtl, W. Oxidative Stress in Cardiovascular Diseases: Still a Therapeutic Target? Nutrients 2019, 11, 2090. [CrossRef]

53. Hong, J.; Kim, K.; Kim, J.H.; Park, Y. The Role of Endoplasmic Reticulum Stress in Cardiovascular Disease and Exercise. Int. J. Vasc. Med. 2017, 2017, 2049217. [CrossRef]

54. Incalza, M.A.; D'Oria, R.; Natalicchio, A.; Perrini, S.; Laviola, L.; Giorgino, F. Oxidative stress and reactive oxygen species in endothelial dysfunction associated with cardiovascular and metabolic diseases. Vasc. Pharmacol. 2018, 100, 1-19. [CrossRef]

55. Younce, C.W.; Wang, K.K.; Kolattukudy, P.E. Hyperglycaemia-induced cardiomyocyte death is mediated via MCP-1 production and induction of a novel zinc-finger protein MCPIP. Cardiovasc. Res. 2010, 87, 665-674. [CrossRef]

56. Borradaile, N.M.; Han, X.; Harp, J.D.; Gale, S.E.; Ory, D.S.; Schaffer, J.E. Disruption of endoplasmic reticulum structure and integrity in lipotoxic cell death. J. Lipid Res. 2006, 47, 2726-2737. [CrossRef] 
57. Dong, Y.; Zhang, M.; Wang, S.; Liang, B.; Zhao, Z.; Liu, C.; Wu, M.; Choi, H.C.; Lyons, T.J.; Zou, M.H. Activation of AMP-activated protein kinase inhibits oxidized LDL-triggered endoplasmic reticulum stress in vivo. Diabetes 2010, 59, 1386-1396. [CrossRef]

58. Burgos-Moron, E.; Abad-Jimenez, Z.; Maranon, A.M.; Iannantuoni, F.; Escribano-Lopez, I.; Lopez-Domenech, S.; Salom, C.; Jover, A.; Mora, V.; Roldan, I.; et al. Relationship Between Oxidative Stress, ER Stress, and Inflammation in Type 2 Diabetes: The Battle Continues. J. Clin. Med. 2019, 8, 1385. [CrossRef]

59. Ozcan, U.; Cao, Q.; Yilmaz, E.; Lee, A.H.; Iwakoshi, N.N.; Ozdelen, E.; Tuncman, G.; Gorgun, C.; Glimcher, L.H.; Hotamisligil, G.S Endoplasmic reticulum stress links obesity, insulin action, and type 2 diabetes. Science 2004, 306, 457-461. [CrossRef] [PubMed]

60. Robson, R.; Kundur, A.R.; Singh, I. Oxidative stress biomarkers in type 2 diabetes mellitus for assessment of cardiovascular disease risk. Diabetes. Metab. Synd. 2018, 12, 455-462. [CrossRef] [PubMed]

61. Ozcan, U.; Yilmaz, E.; Ozcan, L.; Furuhashi, M.; Vaillancourt, E.; Smith, R.O.; Gorgun, C.Z.; Hotamisligil, G.S. Chemical chaperones reduce ER stress and restore glucose homeostasis in a mouse model of type 2 diabetes. Science 2006, 313, 1137-1140. [CrossRef] [PubMed]

62. Liu, Z.; Zhu, H.; He, C.; He, T.; Pan, S.; Zhao, N.; Zhu, L.; Guan, G.; Liu, P.; Zhang, Y.; et al. Nicorandil attenuates high glucose-induced insulin resistance by suppressing oxidative stress-mediated ER stress PERK signaling pathway. BMJ Open Diabetes Res. Care 2021, 9, 4525. [CrossRef] [PubMed]

63. Sharma, H.; Kumar, S. Natural AMPK Activators: An Alternative Approach for the Treatment and Management of Metabolic Syndrome. Curr. Med. Chem. 2017, 24, 1007-1047. [CrossRef]

64. Desjardins, E.M.; Steinberg, G.R. Emerging Role of AMPK in Brown and Beige Adipose Tissue (BAT): Implications for Obesity, Insulin Resistance, and Type 2 Diabetes. Curr. Diab. Rep. 2018, 18, 80. [CrossRef] [PubMed]

65. Kahn, B.B.; Alquier, T.; Carling, D.; Hardie, D.G. AMP-activated protein kinase: Ancient energy gauge provides clues to modern understanding of metabolism. Cell Metab. 2005, 1, 15-25. [CrossRef] [PubMed]

66. Towler, M.C.; Hardie, D.G. AMP-activated protein kinase in metabolic control and insulin signaling. Circ. Res. 2007, 100, 328-341. [CrossRef]

67. Zhao, Y.; Zhu, J.; Liang, H.; Yang, S.; Zhang, Y.; Han, W.; Chen, C.; Cao, N.; Liang, P.; Du, X.; et al. Kang Le Xin Reduces Blood Pressure Through Inducing Endothelial-Dependent Vasodilation by Activating the AMPK-eNOS Pathway. Front. Pharmacol. 2020, 10, 1548. [CrossRef]

68. Hwang, H.J.; Jung, T.W.; Kim, J.W.; Kim, J.A.; Lee, Y.B.; Hong, S.H.; Roh, E.; Choi, K.M.; Baik, S.H.; Yoo, H.J. Protectin DX prevents $\mathrm{H}_{2} \mathrm{O}_{2}$-mediated oxidative stress in vascular endothelial cells via an AMPK-dependent mechanism. Cell. Signal. 2019, 53, 14-21. [CrossRef] [PubMed]

69. Li, J.; Zhu, H.; Shen, E.; Wan, L.; Arnold, J.M.; Peng, T. Deficiency of rac1 blocks NADPH oxidase activation, inhibits endoplasmic reticulum stress, and reduces myocardial remodeling in a mouse model of type 1 diabetes. Diabetes 2010, 59, $2033-2042$. [CrossRef] [PubMed]

70. Lee, S.R.; An, E.J.; Kim, J.; Bae, Y.S. Function of NADPH Oxidases in Diabetic Nephropathy and Development of Nox Inhibitors. Biomol. Ther. (Seoul) 2020, 28, 25-33. [CrossRef] [PubMed]

71. Mohammad, G.; Duraisamy, A.J.; Kowluru, A.; Kowluru, R.A. Functional Regulation of an Oxidative Stress Mediator, Rac1, in Diabetic Retinopathy. Mol. Neurobiol. 2019, 56, 8643-8655. [CrossRef]

72. Ouerd, S.; Idris-Khodja, N.; Trindade, M.; Ferreira, N.S.; Berillo, O.; Coelho, S.C.; Neves, M.F.; Jandeleit-Dahm, K.A.; Paradis, P.; Schiffrin, E.L. Endothelium-restricted endothelin-1 overexpression in type 1 diabetes worsens atherosclerosis and immune cell infiltration via NOX1. Cardiovasc. Res. 2021, 117, 1144-1153. [CrossRef]

73. Narkar, V.A.; Downes, M.; Yu, R.T.; Embler, E.; Wang, Y.X.; Banayo, E.; Mihaylova, M.M.; Nelson, M.C.; Zou, Y.H.; Juguilon, H.; et al. AMPK and PPAR delta Agonists are exercise mimetics. Cell 2008, 134, 405-415. [CrossRef] [PubMed]

74. Peters, J.M.; Lee, S.S.; Li, W.; Ward, J.M.; Gavrilova, O.; Everett, C.; Reitman, M.L.; Hudson, L.D.; Gonzalez, F.J. Growth, adipose, brain, and skin alterations resulting from targeted disruption of the mouse peroxisome proliferator-activated receptor beta(delta). Mol. Cell. Biol. 2000, 20, 5119-5128. [CrossRef] [PubMed]

75. Piqueras, L.; Reynolds, A.R.; Hodivala-Dilke, K.M.; Alfranca, A.; Redondo, J.M.; Hatae, T.; Tanabe, T.; Warner, T.D.; Bishop-Bailey, D. Activation of PPARbeta/delta induces endothelial cell proliferation and angiogenesis. Arterioscler. Thromb. Vasc. Biol. 2007, 27, 63-69. [CrossRef]

76. Cheang, W.S.; Wong, W.T.; Wang, L.; Cheng, C.K.; Lau, C.W.; Ma, R.C.W.; Xu, A.; Wang, N.; Huang, Y.; Tian, X.Y. Resveratrol ameliorates endothelial dysfunction in diabetic and obese mice through sirtuin 1 and peroxisome proliferator-activated receptor delta. Pharmacol. Res. 2019, 139, 384-394. [CrossRef]

77. Tanaka, T.; Yamamoto, J.; Iwasaki, S.; Asaba, H.; Hamura, H.; Ikeda, Y.; Watanabe, M.; Magoori, K.; Ioka, R.X.; Tachibana, K.; et al. Activation of peroxisome proliferator-activated receptor delta induces fatty acid beta-oxidation in skeletal muscle and attenuates metabolic syndrome. Proc. Natl. Acad. Sci. USA 2003, 100, 15924-15929. [CrossRef] [PubMed]

78. Wang, Y.X.; Lee, C.H.; Tiep, S.; Yu, R.T.; Ham, J.; Kang, H.; Evans, R.M. Peroxisome-proliferator-activated receptor delta activates fat metabolism to prevent obesity. Cell 2003, 113, 159-170. [CrossRef]

79. Cohen, G.; Riahi, Y.; Shamni, O.; Guichardant, M.; Chatgilialoglu, C.; Ferreri, C.; Kaiser, N.; Sasson, S. Role of Lipid Peroxidation and PPAR-delta in Amplifying Glucose-Stimulated Insulin Secretion. Diabetes 2011, 60, 2830-2842. [CrossRef]

80. Kang, K.; Reilly, S.M.; Karabacak, V.; Gangl, M.R.; Fitzgerald, K.; Hatano, B.; Lee, C.H. Adipocyte-derived Th2 cytokines and myeloid PPAR delta regulate macrophage polarization and insulin sensitivity. Cell Metab. 2008, 7, 485-495. [CrossRef] 
81. Lee, C.H.; Chawla, A.; Urbiztondo, N.; Liao, D.; Boisvert, W.A.; Evans, R.M.; Curtiss, L.K. Transcriptional repression of atherogenic inflammation: Modulation by PPARdelta. Science 2003, 302, 453-457. [CrossRef]

82. Tian, X.Y.; Wong, W.T.; Wang, N.P.; Lu, Y.; Cheang, W.S.; Liu, J.; Liu, L.M.; Liu, Y.H.; Lee, S.S.T.; Chen, Z.Y.; et al. PPAR delta Activation Protects Endothelial Function in Diabetic Mice. Diabetes 2012, 61, 3285-3293. [CrossRef]

83. Liu, F.; Fang, S.; Liu, X.; Li, J.; Wang, X.; Cui, J.; Chen, T.; Li, Z.; Yang, F.; Tian, J.; et al. Omentin-1 protects against high glucose-induced endothelial dysfunction via the AMPK/PPARdelta signaling pathway. Biochem. Pharmacol. 2020, 174, 113830. [CrossRef] [PubMed]

84. Zhou, J.; Zhe, R.; Guo, X.; Chen, Y.; Zou, Y.; Zhou, L.; Wang, Z. The Role of PPARdelta Agosnist GW501516 in Rats with Gestational Diabetes Mellitus. Diabetes Metab. Syndr. Obes. 2020, 13, 2307-2316. [CrossRef] [PubMed]

85. Mather, K.J.; Verma, S.; Anderson, T.J. Improved endothelial function with metformin in type 2 diabetes mellitus. J. Am. Coll. Cardiol. 2001, 37, 1344-1350. [CrossRef]

86. Tangney, N.; De Buitleir, C.; O’Brien, T.; Liew, A. Efficacy and safety of initial combined therapy with metformin plus a dipeptidyl peptidase-4 inhibitor versus metformin monotherapy in type 2 diabetes mellitus: A systematic review and meta-analysis of phase 3 randomised controlled trials. Ir. J. Med. Sci. 2019, 188, S248.

87. Adler, A.I. Cardiovascular risk reduction in diabetes: Underemphasised and overdue. Messages from major trials. Clin. Med. 2001, 1, 472-477. [CrossRef]

88. Hundal, R.S.; Krssak, M.; Dufour, S.; Laurent, D.; Lebon, V.; Chandramouli, V.; Inzucchi, S.E.; Schumann, W.C.; Petersen, K.F.; Landau, B.R.; et al. Mechanism by which metformin reduces glucose production in type 2 diabetes. Diabetes 2000, 49, 2063-2069. [CrossRef] [PubMed]

89. Gundewar, S.; Calvert, J.W.; Jha, S.; Toedt-Pingel, I.; Ji, S.Y.; Nunez, D.; Ramachandran, A.; Anaya-Cisneros, M.; Tian, R.; Lefer, D.J. Activation of AMP-activated protein kinase by metformin improves left ventricular function and survival in heart failure. Circ. Res. 2009, 104, 403-411. [CrossRef] [PubMed]

90. Srinivasan, M.P.; Bhopale, K.K.; Caracheo, A.A.; Kaphalia, L.; Loganathan, G.; Balamurugan, A.N.; Rastellini, C.; Kaphalia, B.S. Differential cytotoxicity, ER/oxidative stress, dysregulated AMPKalpha signaling, and mitochondrial stress by ethanol and its metabolites in human pancreatic acinar cells. Alcohol. Clin. Exp. Res. 2021, 45, 961-978. [CrossRef] [PubMed]

91. Cheang, W.S.; Tian, X.Y.; Wong, W.T.; Lau, C.W.; Lee, S.S.; Chen, Z.Y.; Yao, X.; Wang, N.; Huang, Y. Metformin protects endothelial function in diet-induced obese mice by inhibition of endoplasmic reticulum stress through $5^{\prime}$ adenosine monophosphate-activated protein kinase-peroxisome proliferator-activated receptor delta pathway. Arterioscler. Thromb. Vasc. Biol. 2014, 34, 830-836. [CrossRef] [PubMed]

92. Wang, G.; Cui, W.; Chen, S.; Shao, Z.; Li, Y.; Wang, W.; Mao, L.; Li, J.; Mei, X. Metformin alleviates high glucose-induced ER stress and inflammation by inhibiting the interaction between caveolin1 and AMPKalpha in rat astrocytes. Biochem. Biophys. Res. Commun. 2021, 534, 908-913. [CrossRef]

93. Chen, C.; Kassan, A.; Castaneda, D.; Gabani, M.; Choi, S.K.; Kassan, M. Metformin prevents vascular damage in hypertension through the AMPK/ER stress pathway. Hypertens. Res. 2019, 42, 960-969. [CrossRef]

94. Cheang, W.S.; Wong, W.T.; Zhao, L.; Xu, J.; Wang, L.; Lau, C.W.; Chen, Z.Y.; Ma, R.C.; Xu, A.; Wang, N.; et al. PPARdelta Is Required for Exercise to Attenuate Endoplasmic Reticulum Stress and Endothelial Dysfunction in Diabetic Mice. Diabetes 2017, 66, 519-528. [CrossRef]

95. Li, J.M.; Wang, J.J.; Yu, Q.; Wang, M.; Zhang, S.X. Endoplasmic reticulum stress is implicated in retinal inflammation and diabetic retinopathy. FEBS Lett. 2009, 583, 1521-1527. [CrossRef] [PubMed]

96. Peng, Q.H.; Tong, P.; Gu, L.M.; Li, W.J. Astragalus polysaccharide attenuates metabolic memory-triggered ER stress and apoptosis via regulation of miR-204/SIRT1 axis in retinal pigment epithelial cells. Biosci. Rep. 2020, 40, BSR20192121. [CrossRef] [PubMed]

97. Chen, Y.; Wang, J.J.; Li, J.; Hosoya, K.I.; Ratan, R.; Townes, T.; Zhang, S.X. Activating transcription factor 4 mediates hyperglycaemia-induced endothelial inflammation and retinal vascular leakage through activation of STAT3 in a mouse model of type 1 diabetes. Diabetologia 2012, 55, 2533-2545. [CrossRef]

98. Hopfgarten, J.; Stenwall, P.A.; Wiberg, A.; Anagandula, M.; Ingvast, S.; Rosenling, T.; Korsgren, O.; Skog, O. Gene expression analysis of human islets in a subject at onset of type 1 diabetes. Acta Diabetol. 2014, 51, 199-204. [CrossRef] [PubMed]

99. Galan, M.; Kassan, M.; Choi, S.K.; Partyka, M.; Trebak, M.; Henrion, D.; Matrougui, K. A novel role for epidermal growth factor receptor tyrosine kinase and its downstream endoplasmic reticulum stress in cardiac damage and microvascular dysfunction in type 1 diabetes mellitus. Hypertension 2012, 60, 71-80. [CrossRef]

100. Zou, W.J.; Zou, C.; Zhao, M.J.; Zheng, Z. ASK1 induces retinal microvascular endothelial cell apoptosis through ER stressassociated pathway. Int. J. Clin. Exp. Pathol. 2019, 12, 1324-1332. [PubMed]

101. Ju, X.; Yang, X.; Yan, T.; Chen, H.; Song, Z.; Zhang, Z.; Wu, W.; Wang, Y. EGFR inhibitor, AG1478, inhibits inflammatory infiltration and angiogenesis in mice with diabetic retinopathy. Clin. Exp. Pharmacol. Physiol. 2019, 46, 75-85. [CrossRef] [PubMed]

102. Amin, A.; Choi, S.K.; Galan, M.; Kassan, M.; Partyka, M.; Kadowitz, P.; Henrion, D.; Trebak, M.; Belmadani, S.; Matrougui, K. Chronic inhibition of endoplasmic reticulum stress and inflammation prevents ischaemia-induced vascular pathology in type II diabetic mice. J. Pathol. 2012, 227, 165-174. [CrossRef]

103. Song, J.; Li, J.; Hou, F.; Wang, X.; Liu, B. Mangiferin inhibits endoplasmic reticulum stress-associated thioredoxin-interacting protein/NLRP3 inflammasome activation with regulation of AMPK in endothelial cells. Metabolism 2015, 64, 428-437. [CrossRef] 
104. Aswal, S.; Kumar, A.; Chauhan, A.; Semwal, R.B.; Kumar, A.; Semwal, D.K. A Molecular Approach on the Protective Effects of Mangiferin Against Diabetes and Diabetes-related Complications. Curr. Diabetes Rev. 2020, 16, 690-698. [CrossRef] [PubMed]

105. Leng, B.; Li, C.; Sun, Y.; Zhao, K.; Zhang, L.; Lu, M.L.; Wang, H.X. Protective Effect of Astragaloside IV on High Glucose-Induced Endothelial Dysfunction via Inhibition of P2X7R Dependent P38 MAPK Signaling Pathway. Oxid. Med. Cell. Longev. 2020, 2020, 5070415. [CrossRef]

106. Civelek, M.; Manduchi, E.; Riley, R.J.; Stoeckert, C.J., Jr.; Davies, P.F. Chronic endoplasmic reticulum stress activates unfolded protein response in arterial endothelium in regions of susceptibility to atherosclerosis. Circ. Res. 2009, 105, 453-461. [CrossRef] [PubMed]

107. Dong, Y.; Zhang, M.; Liang, B.; Xie, Z.; Zhao, Z.; Asfa, S.; Choi, H.C.; Zou, M.H. Reduction of AMP-activated protein kinase alpha2 increases endoplasmic reticulum stress and atherosclerosis in vivo. Circulation 2010, 121, 792-803. [CrossRef] [PubMed]

108. Muller, C.; Salvayre, R.; Negre-Salvayre, A.; Vindis, C. HDLs inhibit endoplasmic reticulum stress and autophagic response induced by oxidized LDLs. Cell Death Differ. 2011, 18, 817-828. [CrossRef] [PubMed]

109. Taborda, N.A.; Blanquiceth, Y.; Urcuqui-Inchima, S.; Latz, E.; Hernandez, J.C. High-Density Lipoproteins Decrease Proinflammatory Activity and Modulate the Innate Immune Response. J. Interferon Cytokine Res. 2019, 39, 760-770. [CrossRef]

110. Sulliman, N.C.; Ghaddar, B.; Gence, L.; Patche, J.; Rastegar, S.; Meilhac, O.; Diotel, N. HDL biodistribution and brain receptors in zebrafish, using HDLs as vectors for targeting endothelial cells and neural progenitors. Sci. Rep. UK 2021, 11, 6439. [CrossRef]

111. Tufanli, O.; Telkoparan Akillilar, P.; Acosta-Alvear, D.; Kocaturk, B.; Onat, U.I.; Hamid, S.M.; Cimen, I.; Walter, P.; Weber, C.; Erbay, E. Targeting IRE1 with small molecules counteracts progression of atherosclerosis. Proc. Natl. Acad. Sci. USA 2017, 114, E1395-E1404. [CrossRef]

112. Abdullah, A.; Ravanan, P. Kaempferol mitigates Endoplasmic Reticulum Stress Induced Cell Death by targeting caspase 3/7. Sci. Rep. 2018, 8, 2189. [CrossRef]

113. Xiong, W.Q.; Fei, M.Z.; Wu, C.T.; Wang, W.; Luo, R.; Shen, L.P.; Zhang, Z. Atorvastatin inhibits endoplasmic reticulum stress through AMPK signaling pathway in atherosclerosis in mice. Exp. Ther. Med. 2020, 19, 2266-2272. [CrossRef]

114. Hong, J.; Kim, K.; Park, E.; Lee, J.; Markofski, M.M.; Marrelli, S.P.; Park, Y. Exercise ameliorates endoplasmic reticulum stress-mediated vascular dysfunction in mesenteric arteries in atherosclerosis. Sci. Rep. 2018, 8, 7938. [CrossRef] [PubMed]

115. Wu, J.; Pan, W.; Wang, C.; Dong, H.; Xing, L.; Hou, J.; Fang, S.; Li, H.; Yang, F.; Yu, B. H2S attenuates endoplasmic reticulum stress in hypoxia-induced pulmonary artery hypertension. Biosci. Rep. 2019, 39, BSR20190304. [CrossRef] [PubMed]

116. Young, C.N.; Cao, X.; Guruju, M.R.; Pierce, J.P.; Morgan, D.A.; Wang, G.; Iadecola, C.; Mark, A.L.; Davisson, R.L. ER stress in the brain subfornical organ mediates angiotensin-dependent hypertension. J. Clin. Investig. 2012, 122, 3960-3964. [CrossRef]

117. Horwath, J.A.; Hurr, C.; Butler, S.D.; Guruju, M.; Cassell, M.D.; Mark, A.L.; Davisson, R.L.; Young, C.N. Obesity-induced hepatic steatosis is mediated by endoplasmic reticulum stress in the subfornical organ of the brain. JCI Insight 2017, 2, e90170. [CrossRef] [PubMed]

118. Kassan, M.; Galan, M.; Partyka, M.; Saifudeen, Z.; Henrion, D.; Trebak, M.; Matrougui, K. Endoplasmic reticulum stress is involved in cardiac damage and vascular endothelial dysfunction in hypertensive mice. Arterioscler. Thromb. Vasc. Biol. 2012, 32, 1652-1661. [CrossRef] [PubMed]

119. Spitler, K.M.; Matsumoto, T.; Webb, R.C. Suppression of endoplasmic reticulum stress improves endothelium-dependent contractile responses in aorta of the spontaneously hypertensive rat. Am. J. Physiol. Heart Circ. Physiol. 2013, 305, H344-H353. [CrossRef]

120. Cheang, W.S.; Ngai, C.Y.; Tam, Y.Y.; Tian, X.Y.; Wong, W.T.; Zhang, Y.; Lau, C.W.; Chen, Z.Y.; Bian, Z.X.; Huang, Y.; et al. Black tea protects against hypertension-associated endothelial dysfunction through alleviation of endoplasmic reticulum stress. Sci. Rep. UK 2015, 5, 10340. [CrossRef] [PubMed]

121. Murugan, D.; Lau, Y.S.; Lau, C.W.; Mustafa, M.R.; Huang, Y. Angiotensin 1-7 Protects against Angiotensin II-Induced Endoplasmic Reticulum Stress and Endothelial Dysfunction via Mas Receptor. PLoS ONE 2015, 10, e0145413.

122. Spitler, K.M.; Webb, R.C. Endoplasmic reticulum stress contributes to aortic stiffening via proapoptotic and fibrotic signaling mechanisms. Hypertension 2014, 63, e40-e45. [CrossRef]

123. Takayanagi, T.; Kawai, T.; Forrester, S.J.; Obama, T.; Tsuji, T.; Fukuda, Y.; Elliott, K.J.; Tilley, D.G.; Davisson, R.L.; Park, J.Y.; et al. Role of epidermal growth factor receptor and endoplasmic reticulum stress in vascular remodeling induced by angiotensin II. Hypertension 2015, 65, 1349-1355. [CrossRef]

124. Obama, T.; Takayanagi, T.; Kobayashi, T.; Bourne, A.M.; Elliott, K.J.; Charbonneau, M.; Dubois, C.M.; Eguchi, S. Vascular induction of a disintegrin and metalloprotease 17 by angiotensin II through hypoxia inducible factor 1alpha. Am. J. Hypertens. 2015, 28, 10-14. [CrossRef] [PubMed]

125. Pan, T.; Zhang, L.; Miao, K.; Wang, Y. A crucial role of endoplasmic reticulum stress in cellular responses during pulmonary arterial hypertension. Am. J. Transl. Res. 2020, 12, 1481-1490. [PubMed]

126. Yang, J.; Griffiths, M.; Nies, M.K.; Brandal, S.; Damico, R.; Vaidya, D.; Tao, X.T.; Simpson, C.E.; Kolb, T.M.; Mathai, S.C.; et al. Insulin-like growth factor binding protein-2: A new circulating indicator of pulmonary arterial hypertension severity and survival. BMC Med. 2020, 18, 268. [CrossRef] [PubMed]

127. Zhuan, B.; Wang, X.; Wang, M.D.; Li, Z.C.; Yuan, Q.; Xie, J.; Yang, Z. Hypoxia induces pulmonary artery smooth muscle dysfunction through mitochondrial fragmentation-mediated endoplasmic reticulum stress. Aging US 2020, 12, 23684-23697. [CrossRef] [PubMed] 
128. Dromparis, P.; Paulin, R.; Stenson, T.H.; Haromy, A.; Sutendra, G.; Michelakis, E.D. Attenuating endoplasmic reticulum stress as a novel therapeutic strategy in pulmonary hypertension. Circulation 2013, 127, 115-125. [CrossRef] [PubMed]

129. Koyama, M.; Furuhashi, M.; Ishimura, S.; Mita, T.; Fuseya, T.; Okazaki, Y.; Yoshida, H.; Tsuchihashi, K.; Miura, T. Reduction of endoplasmic reticulum stress by 4-phenylbutyric acid prevents the development of hypoxia-induced pulmonary arterial hypertension. Am. J. Physiol. Heart Circ. Physiol. 2014, 306, H1314-H1323. [CrossRef]

130. Wu, Y.; Adi, D.; Long, M.; Wang, J.; Liu, F.; Gai, M.T.; Aierken, A.; Li, M.Y.; Li, Q.; Wu, L.Q.; et al. 4-Phenylbutyric Acid Induces Protection against Pulmonary Arterial Hypertension in Rats. PLoS ONE 2016, 11, e0157538. [CrossRef]

131. Mao, S.Z.; Fan, X.F.; Xue, F.; Chen, R.; Chen, X.Y.; Yuan, G.S.; Hu, L.G.; Liu, S.F.; Gong, Y.S. Intermedin modulates hypoxic pulmonary vascular remodeling by inhibiting pulmonary artery smooth muscle cell proliferation. Pulm. Pharmacol. Ther. 2014, 27, 1-9. [CrossRef]

132. Cao, X.; He, Y.; Li, X.; Xu, Y.; Liu, X. The IRE1alpha-XBP1 pathway function in hypoxia-induced pulmonary vascular remodeling, is upregulated by quercetin, inhibits apoptosis and partially reverses the effect of quercetin in PASMCs. Am. J. Transl. Res. 2019, 11, 641-654.

133. Sutendra, G.; Dromparis, P.; Wright, P.; Bonnet, S.; Haromy, A.; Hao, Z.; McMurtry, M.S.; Michalak, M.; Vance, J.E.; Sessa, W.C.; et al. The role of Nogo and the mitochondria-endoplasmic reticulum unit in pulmonary hypertension. Sci. Transl. Med. 2011, 3, 88ra55. [CrossRef]

134. Sutendra, G.; Dromparis, P.; Bonnet, S.; Haromy, A.; McMurtry, M.S.; Bleackley, R.C.; Michelakis, E.D. Pyruvate dehydrogenase inhibition by the inflammatory cytokine TNFalpha contributes to the pathogenesis of pulmonary arterial hypertension. J. Mol. Med. 2011, 89, 771-783. [CrossRef] [PubMed]

135. Ghatnekar, A.; Chrobak, I.; Reese, C.; Stawski, L.; Seta, F.; Wirrig, E.; Paez-Cortez, J.; Markiewicz, M.; Asano, Y.; Harley, R.; et al. Endothelial GATA-6 Deficiency Promotes Pulmonary Arterial Hypertension. Am. J. Pathol. 2013, 182, 2391-2406. [CrossRef]

136. Ichihara, A.; Toyama, T.; Kudryashova, T.; Lenna, S.; Looney, A.; Shen, Y.; Avolio, T.; Goncharov, D.; Lafyatis, R.A.; Seta, F.; et al. Endothelial GATA6 Coordinates Cross-Talk Between BMP and Oxidative Stress Axis in Pulmonary Arterial Hypertension. Am. J. Respir Crit. Care 2020, 201, A6363.

137. Lenna, S.; Farina, A.G.; Martyanov, V.; Christmann, R.B.; Wood, T.A.; Farber, H.W.; Scorza, R.; Whitfield, M.L.; Lafyatis, R.; Trojanowska, M. Increased expression of endoplasmic reticulum stress and unfolded protein response genes in peripheral blood mononuclear cells from patients with limited cutaneous systemic sclerosis and pulmonary arterial hypertension. Arthritis Rheum. 2013, 65, 1357-1366. [CrossRef]

138. Outinen, P.A.; Sood, S.K.; Pfeifer, S.I.; Pamidi, S.; Podor, T.J.; Li, J.; Weitz, J.I.; Austin, R.C. Homocysteine-induced endoplasmic reticulum stress and growth arrest leads to specific changes in gene expression in human vascular endothelial cells. Blood 1999, 94, 959-967. [CrossRef] [PubMed]

139. Austin, R.C.; Lentz, S.R.; Werstuck, G.H. Role of hyperhomocysteinemia in endothelial dysfunction and atherothrombotic disease. Cell Death Differ. 2004, 11 (Suppl. 1), S56-S64. [CrossRef]

140. Ponce-Ruiz, N.; Murillo-Gonzalez, F.E.; Rojas-Garcia, A.E.; Barron-Vivanco, B.S.; Bernal-Hernandez, Y.Y.; Gonzalez-Arias, C.A.; Ortega-Cervantes, L.; Ponce-Gallegos, J.; Lopez-Guarnido, O.; Medina-Diaz, I.M. PON1 status and homocysteine levels as potential biomarkers for cardiovascular disease. Exp. Gerontol. 2020, 140, 111062. [CrossRef] [PubMed]

141. Zhang, C.; Cai, Y.; Adachi, M.T.; Oshiro, S.; Aso, T.; Kaufman, R.J.; Kitajima, S. Homocysteine induces programmed cell death in human vascular endothelial cells through activation of the unfolded protein response. J. Biol. Chem. 2001, 276, 35867-35874. [CrossRef]

142. Hossain, G.S.; van Thienen, J.V.; Werstuck, G.H.; Zhou, J.; Sood, S.K.; Dickhout, J.G.; de Koning, A.B.L.; Tang, D.; Wu, D.C.; Falk, E.; et al. TDAG51 is induced by homocysteine, promotes detachment-mediated programmed cell death, and contributes to the development of atherosclerosis in hyperhomocysteinemia. J. Biol. Chem. 2003, 278, 30317-30327. [CrossRef] [PubMed]

143. Wang, X.C.; Sun, W.T.; Yu, C.M.; Pun, S.H.; Underwood, M.J.; He, G.W.; Yang, Q. ER stress mediates homocysteine-induced endothelial dysfunction: Modulation of IKCa and SKCa channels. Atherosclerosis 2015, 242, 191-198. [CrossRef]

144. Liu, X.; Qin, Z.X.; Liu, C.; Song, M.B.; Luo, X.L.; Zhao, H.Q.; Qian, D.H.; Chen, J.F.; Huang, L. Nox4 and soluble epoxide hydrolase synergistically mediate homocysteine-induced inflammation in vascular smooth muscle cells. Vasc. Pharmacol. 2019, 120, 106544. [CrossRef] [PubMed]

145. Zhang, D.; Xie, X.; Chen, Y.; Hammock, B.D.; Kong, W.; Zhu, Y. Homocysteine upregulates soluble epoxide hydrolase in vascular endothelium in vitro and in vivo. Circ. Res. 2012, 110, 808-817. [CrossRef] [PubMed]

146. Khadir, A.; Kavalakatt, S.; Madhu, D.; Cherian, P.; Al-Mulla, F.; Abubaker, J.; Tiss, A. Soluble Epoxide Hydrolase 2 Expression Is Elevated in Obese Humans and Decreased by Physical Activity. Int. J. Mol. Sci. 2020, 21, 2056. [CrossRef] [PubMed]

147. Wu, S.; Gao, X.; Yang, S.; Meng, M.; Yang, X.; Ge, B. The role of endoplasmic reticulum stress in endothelial dysfunction induced by homocysteine thiolactone. Fundam. Clin. Pharmacol. 2015, 29, 252-259. [CrossRef] [PubMed]

148. Zhou, Y.; Zhao, L.; Zhang, Z.; Lu, X. Protective Effect of Enalapril against Methionine-Enriched Diet-Induced Hypertension: Role of Endoplasmic Reticulum and Oxidative Stress. Biomed. Res. Int. 2015, 2015, 724876. [CrossRef] [PubMed]

149. Kil, J.S.; Jeong, S.O.; Chung, H.T.; Pae, H.O. Piceatannol attenuates homocysteine-induced endoplasmic reticulum stress and endothelial cell damage via heme oxygenase-1 expression. Amino Acids 2017, 49, 735-745. [CrossRef] [PubMed]

150. Jia, F.; Wu, C.; Chen, Z.; Lu, G.; Sun, J. Atorvastatin attenuates atherosclerotic plaque destabilization by inhibiting endoplasmic reticulum stress in hyperhomocysteinemic mice. Mol. Med. Rep. 2016, 13, 3574-3580. [CrossRef] 
151. Jia, F.; Wu, C.F.; Chen, Z.Y.; Lu, G.P. Atorvastatin Inhibits Homocysteine-Induced Endoplasmic Reticulum Stress through Activation of AMP-Activated Protein Kinase. Cardiovasc. Ther. 2012, 30, 317-325. [CrossRef]

152. Zhu, L.; Jia, F.; Wei, J.; Yu, Y.; Yu, T.; Wang, Y.; Sun, J.; Luo, G. Salidroside protects against homocysteine-induced injury in human umbilical vein endothelial cells via the regulation of endoplasmic reticulum stress. Cardiovasc. Ther. 2017, 35, 33-39. [CrossRef]

153. Hu, H.; Wang, C.; Jin, Y.; Meng, Q.; Liu, Q.; Liu, K.; Sun, H. Alpha-lipoic acid defends homocysteine-induced endoplasmic reticulum and oxidative stress in HAECs. Biomed. Pharmacother. 2016, 80, 63-72. [CrossRef]

154. Cheng, C.K.; Luo, J.Y.; Lau, C.W.; Cho, W.C.; Ng, C.F.; Ma, R.C.W.; Tian, X.Y.; Huang, Y. A GLP-1 analog lowers ER stress and enhances protein folding to ameliorate homocysteine-induced endothelial dysfunction. Acta Pharmacol. Sin. 2021. [CrossRef]

155. Swynghedauw, B. Molecular mechanisms of myocardial remodeling. Physiol. Rev. 1999, 79, 215-262. [CrossRef] [PubMed]

156. Li, W.G.; Zaheer, A.; Coppey, L.; Oskarsson, H.J. Activation of JNK in the remote myocardium after large myocardial infarction in rats. Biochem. Biophys. Res. Commun. 1998, 246, 816-820. [CrossRef] [PubMed]

157. Hori, M.; Nishida, K. Oxidative stress and left ventricular remodelling after myocardial infarction. Cardiovasc. Res. 2009, 81, 457-464. [CrossRef] [PubMed]

158. Yamaguchi, O.; Higuchi, Y.; Hirotani, S.; Kashiwase, K.; Nakayama, H.; Hikoso, S.; Takeda, T.; Watanabe, T.; Asahi, M.; Taniike, M.; et al. Targeted deletion of apoptosis signal-regulating kinase 1 attenuates left ventricular remodeling. Proc. Natl. Acad. Sci. USA 2003, 100, 15883-15888. [CrossRef]

159. Ma, R.F.; Chen, G.; Li, H.Z.; Zhang, Y.; Liu, Y.M.; He, H.Q.; Liu, C.Y.; Xie, Z.C.; Zhang, Z.P.; Wang, J. Panax Notoginseng Saponins Inhibits Ventricular Remodeling after Myocardial Infarction in Rats Through Regulating ATF3/MAP2K3/p38 MAPK and NF kappa B Pathway. Chin. J. Integr. Med. 2020, 26, 897-904. [CrossRef]

160. Wang, J.; Li, H.Z.; Guo, Y.M.; Zhao, Z.; Zhang, L.; Yang, D.W. Association of TNF-alpha with ventricular arrhythmias during early acute myocardial infraction. Int. J. Clin. Exp. Pathol. 2016, 9, 6136-6144.

161. Li, F.F.; Yang, Y.M.; Xue, C.Y.; Tan, M.T.; Xu, L.; Gao, J.B.; Xu, L.H.; Zong, J.; Qian, W.H. Zinc Finger Protein ZBTB20 protects against cardiac remodelling post-myocardial infarction via ROS-TNF alpha/ASK1/JNK pathway regulation. J. Cell. Mol. Med. 2020, 24, 13383-13396. [CrossRef] [PubMed]

162. Yamamoto, E.; Kataoka, K.; Shintaku, H.; Yamashita, T.; Tokutomi, Y.; Dong, Y.F.; Matsuba, S.; Ichijo, H.; Ogawa, H.; KimMitsuyama, S. Novel mechanism and role of angiotensin II-Induced vascular endothelial injury in hypertensive diastolic heart failure. Arterioscler. Thromb. Vasc. 2007, 27, 2569-2575. [CrossRef] [PubMed]

163. Zhou, X.; Li, Z.C.; Chen, P.P.; Xie, R.F. Primary Mechanism Study of Panax notoginseng Flower (Herb) on Myocardial Infarction in Rats. Cardiol. Res. Pract. 2019, 2019, 8723076. [CrossRef] [PubMed]

164. Russomanno, G.; Corbi, G.; Manzo, V.; Ferrara, N.; Rengo, G.; Puca, A.A.; Latte, S.; Carrizzo, A.; Calabrese, M.C.; Andriantsitohaina, R.; et al. The anti-ageing molecule sirt1 mediates beneficial effects of cardiac rehabilitation. Immun. Ageing $2017,14,7$. [CrossRef] [PubMed]

165. Tajiri, S.; Oyadomari, S.; Yano, S.; Morioka, M.; Gotoh, T.; Hamada, J.I.; Ushio, Y.; Mori, M. Ischemia-induced neuronal cell death is mediated by the endoplasmic reticulum stress pathway involving CHOP. Cell Death Differ. 2004, 11, 403-415. [CrossRef] [PubMed]

166. Wang, H.; Chen, L.; Zhang, X.; Xu, L.; Xie, B.; Shi, H.; Duan, Z.; Zhang, H.; Ren, F. Kaempferol protects mice from dGalN/LPS-induced acute liver failure by regulating the ER stress-Grp78-CHOP signaling pathway. Biomed. Pharmacother. 2019, 111, 468-475. [CrossRef]

167. Tuttolomondo, A.; Daidone, M.; Pinto, A. Endothelial Dysfunction and Inflammation in Ischemic Stroke Pathogenesis. Curr. Pharm. Des. 2020, 26, 4209-4219. [CrossRef]

168. Li, Y.; Zhang, Y.; Fu, H.; Huang, H.; Lu, Q.; Qin, H.; Wu, Y.; Huang, H.; Mao, G.; Wei, Z.; et al. Hes1 Knockdown Exacerbates Ischemic Stroke Following tMCAO by Increasing ER Stress-Dependent Apoptosis via the PERK/eIF2alpha/ATF4/CHOP Signaling Pathway. Neurosci. Bull. 2020, 36, 134-142. [CrossRef] [PubMed]

169. Prentice, H.; Gharibani, P.M.; Ma, Z.; Alexandrescu, A.; Genova, R.; Chen, P.C.; Modi, J.; Menzie, J.; Pan, C.; Tao, R.; et al. Neuroprotective Functions Through Inhibition of ER Stress by Taurine or Taurine Combination Treatments in a Rat Stroke Model. Adv. Exp. Med. Biol. 2017, 975 Pt 1, 193-205.

170. Qiu, J.; Wang, X.; Wu, F.; Wan, L.; Cheng, B.; Wu, Y.; Bai, B. Low Dose of Apelin-36 Attenuates ER Stress-Associated Apoptosis in Rats with Ischemic Stroke. Front. Neurol. 2017, 8, 556. [CrossRef]

171. Wang, Z.; Zhang, H.; Xu, X.; Shi, H.; Yu, X.; Wang, X.; Yan, Y.; Fu, X.; Hu, H.; Li, X.; et al. bFGF inhibits ER stress induced by ischemic oxidative injury via activation of the PI3K/Akt and ERK1/2 pathways. Toxicol. Lett. 2012, 212, 137-146. [CrossRef] [PubMed]

172. Inagi, R. Oxidative stress in cardiovascular disease: A new avenue toward future therapeutic approaches. Recent Pat. Cardiovasc. Drug Discov. 2006, 1, 151-159. [CrossRef] [PubMed]

173. Minamino, T.; Komuro, I.; Kitakaze, M. Endoplasmic Reticulum Stress As a Therapeutic Target in Cardiovascular Disease. Circ. Res. 2010, 107, 1071-1082. [CrossRef]

174. Boyce, M.; Bryant, K.F.; Jousse, C.; Long, K.; Harding, H.P.; Scheuner, D.; Kaufman, R.J.; Ma, D.; Coen, D.M.; Ron, D.; et al. A selective inhibitor of eIF2alpha dephosphorylation protects cells from ER stress. Science 2005, 307, 935-939. [CrossRef]

175. Goldberg, A.L. Development of proteasome inhibitors as research tools and cancer drugs. J. Cell Biol. 2012, 199, 583-588. [CrossRef] [PubMed] 
176. Engin, F.; Yermalovich, A.; Nguyen, T.; Hummasti, S.; Fu, W.; Eizirik, D.L.; Mathis, D.; Hotamisligil, G.S. Restoration of the unfolded protein response in pancreatic beta cells protects mice against type 1 diabetes. Sci. Transl. Med. 2013, 5, 211 ra156. [CrossRef] [PubMed]

177. Kars, M.; Yang, L.; Gregor, M.F.; Mohammed, B.S.; Pietka, T.A.; Finck, B.N.; Patterson, B.W.; Horton, J.D.; Mittendorfer, B.; Hotamisligil, G.S.; et al. Tauroursodeoxycholic Acid May Improve Liver and Muscle but Not Adipose Tissue Insulin Sensitivity in Obese Men and Women. Diabetes 2010, 59, 1899-1905. [CrossRef]

178. Xiao, C.T.; Giacca, A.; Lewis, G.F. Sodium Phenylbutyrate, a Drug With Known Capacity to Reduce Endoplasmic Reticulum Stress, Partially Alleviates Lipid-Induced Insulin Resistance and beta-Cell Dysfunction in Humans. Diabetes 2011, 60, 918-924. [CrossRef] [PubMed]

179. Fiorentino, T.V.; Procopio, T.; Mancuso, E.; Arcidiacono, G.P.; Andreozzi, F.; Arturi, F.; Sciacqua, A.; Perticone, F.; Hribal, M.L.; Sesti, G. SRT1720 counteracts glucosamine-induced endoplasmic reticulum stress and endothelial dysfunction. Cardiovasc. Res. 2015, 107, 295-306. [CrossRef] [PubMed] 